\title{
Effect of Bt-Corn Hybrids on Deoxynivalenol Content in Grain at Harvest
}

\author{
A. W. Schaafsma, D. C. Hooker, T. S. Baute, and L. Illincic-Tamburic, Ridgetown College, University of \\ Guelph, Ontario, Canada
}

\begin{abstract}
Schaafsma, A. W., Hooker, D. C., Baute, T. S., and Illincic-Tamburic, L. 2002. Effect of Bt-corn hybrids on deoxynivalenol content in grain at harvest. Plant Dis. 86:1123-1126.

Concentrations of the mycotoxins deoxynivalenol (DON) and fumonisin $\mathrm{B}_{1}$ in grain were compared among $B t$-transformed corn hybrids and their non- $B t$ isolines on 102 commercial corn fields across Ontario from 1996 to 1999. Intensities of naturally occurring populations of $O s$ trinia nubilalis were assessed from tunneling measurements in the stalks of non- $B t$ isolines in 1996 and 1997. Mean concentrations of fumonisin $B_{1}$ across hybrids were $<0.25 \mu \mathrm{g} \mathrm{g}^{-1}$ in every year of the study. Relationships between the concentration of fumonisin $\mathrm{B}_{1}$ and intensity of $O$. nubilalis or with the use of $B t$ corn hybrids could not be determined because the concentrations of fumonisin $B_{1}$ were below the lower limit of detection in most fields $\left(<0.1 \mu \mathrm{g} \mathrm{g}^{-1}\right)$. However, DON was more prevalent with mean concentrations across fields from $0.42 \mu \mathrm{g} \mathrm{g}^{-1}$ in 1997 to $1.12 \mu \mathrm{g} \mathrm{g}^{-1}$ in 1999. The effect of $B t$ hybrids on reducing concentrations of DON was mainly dependent on the intensity of $O$. nubilalis in each field. Where a high intensity (stalk injury) of $O$. nubilalis was observed ( $>4 \mathrm{~cm}$ of tunnel per stalk in the non- $B t$ ), the use of $B t$ hybrids reduced concentrations of DON by an average of $59 \%$ from concentrations in the non- $B t$ isoline. Where the intensity of $O$. nubilalis was low ( $<4 \mathrm{~cm}$ of tunneling per stalk), concentrations of DON were not different among $B t$ and non- $B t$ hybrids. Concentrations of DON were low and not different between events $B t 11$ and 176 among $B t$ hybrids. A quadratic relationship was developed showing that the concentration of DON increased with intensity of $O$. nubilalis feeding. This study cautiously supports the use of $B t$ corn to reduce the risk of high concentrations of DON at harvest in Ontario.
\end{abstract}

Several fungi are toxigenic in corn; mycotoxins produced from these fungi are a threat to livestock and human health (13). In the more southern regions of corn production in North America, aflatoxins produced by Aspergillus spp. are the dominant concern (21), while in the central regions of the continent, fumonisins produced by some Fusarium spp. of the Liseola taxonomic group are of greater concern (13). However, in the northern regions of North American corn production, Aspergillus does not occur on corn in the field (13) and fumonisins are rare and generally at very low concentrations (14). Fusarium graminearum occurs frequently in northern corn production regions that include eastern Canada, producing several trichothecene toxins and zearalenone (13). The most common and important mycotoxin occurring in corn in the north is deoxynivalenol (DON).

Fusarium fungi may gain entrance to corn ears mainly through the following: infections down the silk channel (22), systemic channels as the corn plants grow from seedlings (17), or wounds caused by

Corresponding author: A. W. Schaafsma E-mail: aschaafs@ ridgetownc.uoguelph.ca

Accepted for publication 20 May 2002.

Publication no. D-2002-0812-02R

(C) 2002 The American Phytopathological Society insects (22). European corn borer (ECB), Ostrinia nubilalis Hübner, is the dominant insect that can wound corn ears in the central and northern production areas in North America. Relationships between insect injury in corn ears and fungal ear rots have been documented for several lepidopterous and coleopterous pests of corn $(1,6,7,18,25)$. McMillian et al. (12) were among the first to show lower concentrations of aflatoxin with ECB resistance in corn in an ECB infestation. Dowd (7) and Dowd et al. (9) demonstrated that controlling chewing insects with insecticides also reduced mycotoxigenic ear molds. The advent of transgenic ECB resistance in corn, with the expression of Bacillus thuringiensis $(B t)$ endotoxins, has led to observations that there was reduced Fusarium ear rot and symptomless kernel infection in $B t$-transformed ECB-resistant corn ears compared with nontransformed corn ears $(16,18)$, and lower concentrations of fumonisin produced in transformed ECBresistant hybrids $(8,15)$. In a review of the safety and advantages of $B t$-transformed corn, Betz et al. (3) suggested reduced concentrations of fungal toxins as one benefit of growing $B t$-transformed corn. However, Dowd (8) cautioned that concentrations of fumonisin may not be reduced in ECB-resistant corn under certain environmental conditions or if ear injury has been caused by other insects.

Relationships between intensities of $\mathrm{ECB}$ and DON and fumonisin $\mathrm{B}_{1}$ have not been reported for northern corn production regions. The objective of this paper was to investigate the effects of $B t$ corn hybrids on DON and fumonisin $\mathrm{B}_{1}$ at harvest, and to complement existing $B t$-corn/mycotoxin information with data from the northern corn production area of North America. This paper is an extension of the work by Baute et al. (2), who showed that $B t$ corn in eastern Canada was economical only when ECB injury was high, and that the benefits were directly related to ECB control.

\section{MATERIALS AND METHODS}

Plot layout. Concentrations of DON and fumonisin were measured in samples of machine-harvested grain from adjacent strips that were planted to a $B t$ corn hybrid, the non- $B t$ isoline, and a non- $B t$ check hybrid. Seventeen commercial corn fields were sampled in 1996, 27 in 1997, 31 in 1998, and 27 in 1999, for a total of 102 pairwise comparisons between $B t$ corn hybrids and isolines. The purpose of the non- $B t$ check hybrids was to compare the advantages, if any, in the use of other non$B t$ corn hybrids for reducing mycotoxins. The non- $B t$ check hybrids were selected from the Ontario Hybrid Corn Performance Trials (Ontario Corn Committee 1997 and 1998) on the basis of their agronomic adaptation to the region, high yield potential, and ability to resist stalk lodging. The fields selected in the survey were among several crop heat unit (CHU [5]) regions in each year, ranging from 2,600 to 3,200 CHU. The width of each strip varied according to the width of planting equipment used by each grower, which ranged from 4 to 12 rows wide. The $B t$ hybrids were either event 176 or $B t 11$ from Syngenta Seeds Inc. All corn hybrids were popular hybrids adapted to each region across Ontario, and they were harvested when moisture content of the grain was between 20 and $30 \%$. These sites were also used for an ECB damage and yield performance study.

Insect assessment. The main purpose for the sites was to investigate the performance of $B t$ corn with respect to ECB injury and yield (2). Only two ECB injury assessments were made in each field, which consisted of stalk tunneling measurements. Injury assessments were not made on corn ears because of resource limitations; therefore, stalk tunneling was used as an index of ECB population intensity. The intensity of ECB infestation was assessed in only 35 of the fields during 1996 and 1997. Ten consecutive plants in 
each of four segments were selected in the center rows of non- $B t$ strips. The first and last segments were at least $12 \mathrm{~m}$ from the front and rear of the field margins to avoid any edge effects; the center two segments were spaced evenly between the first and last segment (minimum space between segments in all fields was $15 \mathrm{~m}$ ). The stalks of selected plants were split lengthwise, and the lengths of tunnels caused by ECB were measured. Intensity of ECB in a field was assumed "low" when an average of $<4 \mathrm{~cm}$ of tunneling was measured per plant, and "high" when $>4 \mathrm{~cm}$ of tunneling was measured per plant. No insecticides were applied to these fields. Ear damage caused by molds or insects other than ECB was not noted.

Sampling and mycotoxin analysis. The strips were harvested in field with commercial harvesting equipment between mid-October and the end of November. Approximately $2 \mathrm{~kg}$ of grain was obtained from each hybrid by removing small samples from the grain unloading auger of the combine. The grain samples were stored in burlap sacks and hung to dry at room temperature for about 3 weeks. The entire sample was ground coarsely through a No. 60 Grist Mill (C.S. Bell Co., Tiffin, OH), with the resulting meal mixed thoroughly by hand. A 250-g subsample of the meal was finely ground through a ROMER grinding/subsampling mill (Model 2A, Romer Labs, Inc., Union, MO). For DON analysis, a 20-g subsample was extracted in a $100-\mathrm{ml}$ mixture of methanol and water (1:9). DON was quantified using competi- tive direct enzyme-linked immunosorbent assay (CD-ELISA) according to Schaafsma et al. (20) using the commercial preparation EZ-Quant DON Plate Kit (Beacon Analytical Systems, Inc., Scarborough, $\mathrm{ME})$. This analytical procedure for DON has a lower limit of detection of $0.2 \mu \mathrm{g} \mathrm{g}^{-1}$. For fumonisin $\mathrm{B}_{1}$ analysis, a 50-g sample of finely ground flour was extracted in 100 $\mathrm{ml}$ of acetonitrile, $4 \% \mathrm{KCl}_{\mathrm{aq}}(9: 1)$, and quantified by thin layer chromatography according to Schaafsma et al. (20); this procedure for fumonisin has a lower limit of detection of $0.1 \mu \mathrm{g} \mathrm{g}^{-1}$.

Statistical analysis. PROC UNIVARIATE (SAS Institute, Cary, NC) was used to test the plausibility of assumptions for ANOVA. DON and fumonisin values were transformed using $\ln (x+0.1)$ to satisfy assumptions of normality. The transformed data were analyzed using PROC MIXED (SAS), with individual strips as the experimental unit. All non- $B t$ check hybrids were removed from subsequent analyses if they were deemed not different $(P=0.05)$ from the non- $B t$ isolines. Data were combined across years when interactions with year were not significant $(P>0.05)$. The year, corn hybrid type (i.e., $B t$ versus non$B t$ ), and categorical intensities of ECB (i.e., low or $<4 \mathrm{~cm}$ of tunneling per plant versus high or $>4 \mathrm{~cm}$ of tunneling per plant) were considered fixed effects. "Field within year" was the blocking term in the RANDOM statement in PROC MIXED. Relationships among DON and ECB tunnel lengths were investigated using PROC REG. Dummy variables were used in

Table 1. Mean deoxynivalenol (DON) concentrations ${ }^{\mathrm{a}}$ across corn $B t$ and isoline hybrids from farm strip trials across Ontario from 1996 to 1999

\begin{tabular}{lccccc}
\hline & $\mathbf{1 9 9 6}$ & $\mathbf{1 9 9 7}$ & $\mathbf{1 9 9 8}$ & $\mathbf{1 9 9 9}$ & $\begin{array}{c}\text { Mean across } \\
\text { years }\end{array}$ \\
\hline Corn hybrid type $\left(\mu \mathrm{g} \mathrm{g}^{-1}\right)$ & & & & & \\
$\quad$ Non- $B t$ isoline & 1.25 & 0.51 & 1.15 & 1.19 & 0.96 \\
$B t$ & 0.45 & 0.36 & 0.69 & 1.06 & 0.57 \\
Mean & 0.73 & 0.42 & 0.89 & 1.12 & 0.77 \\
$P$ value of $t$ test: isoline vs. $B t$ & $<0.0001$ & 0.02 & 0.0019 & 0.51 & $<0.0001$ \\
$\quad$ No. paired observations (fields) & 17 & 27 & 31 & 27 & 102 (total) \\
Range of DON concentrations in samples $\left(\mu \mathrm{g} \mathrm{g}^{-1}\right)$ & & & & \\
$\quad<$ Minimum & $<0.2$ & $<0.2$ & $<0.2$ & $<0.2$ & \\
$\quad$ Maximum & 5.0 & 5.0 & 3.1 & 6.1 & \\
Proportion of samples testing DON-positive $(\%)$ & & & & \\
$\quad$ Non- $B t$ isoline & 94 & 67 & 90 & 85 & \\
$B t$ & 59 & 41 & 74 & 85 & \\
\hline
\end{tabular}

${ }^{a}$ DON concentrations are presented as detransformed means from $\ln (\mathrm{DON}+0.1)$.

${ }^{\mathrm{b}}$ Lower detection limit for DON is $0.2 \mu \mathrm{g} \mathrm{g}^{-1}$.

Table 2. Analysis of variance for year and corn $B t$ versus non- $B t$ hybrid effects on transformed deoxynivalenol (DON) concentrations from 1996 to $1999^{\text {a }}$

\begin{tabular}{lcccc}
\hline Source $^{\mathbf{b}}$ & NDF $^{\mathbf{c}}$ & DDF $^{\mathbf{c}}$ & $\boldsymbol{F}$ & $\boldsymbol{P}>\boldsymbol{F}$ \\
\hline Year & 3 & 96 & 6.16 & 0.0007 \\
Corn type & 1 & 99 & 32.08 & $<0.0001$ \\
Year $\times$ corn type & 3 & 99 & 3.73 & 0.0138 \\
\hline
\end{tabular}

${ }^{a}$ Concentrations of DON were transformed using $\ln (\mathrm{DON}+0.1)$ before analysis.

${ }^{\mathrm{b}}$ Effects of source variables were fixed; field within year was the random effect in SAS PROC MIXED.

${ }^{c} \mathrm{NDF}=$ degrees of freedom in the numerator; $\mathrm{DDF}=$ degrees of freedom in the denominator.

${ }^{\mathrm{d}} B t$ or non- $B t$ isoline.
PROC REG (4) to test the effect of $B t$ versus non- $B t$ hybrids on this relationship.

Weather data estimates. A partial account of year-to-year variability in concentrations of DON and fumonisin was attempted using estimates of daily rainfall and air temperatures across field locations. Weather variables were obtained for each field using data from the nearest Environment Canada weather station within $50 \mathrm{~km}$ of each field location.

\section{RESULTS}

No relationships were found between the concentration of fumonisin $\mathrm{B}_{1}$ and $\mathrm{ECB}$ injury, or with the use of $B t$ corn hybrids. In fact, only a small proportion of grain samples tested positive for fumonisin $\mathrm{B}_{1}$ (i.e., $>0.1 \mu \mathrm{g} \mathrm{g}^{-1}$ ); $6 \%$ of the samples were fumonisin $\mathrm{B}_{1}$-positive in $1996,56 \%$ in 1997, 26\% in 1998, and 44\% in 1999. Mean concentrations of fumonisin $B_{1}$ in grain samples across all hybrids were $<0.1$ $\mu \mathrm{g} \mathrm{g} \mathrm{g}^{-1}$ in $1996,0.23 \mu \mathrm{g} \mathrm{g}^{-1}$ in $1997,0.11 \mu \mathrm{g}$ $\mathrm{g}^{-1}$ in 1998 , and $0.25 \mu \mathrm{g} \mathrm{g}^{-1}$ in 1999. The maximum concentration of fumonisin $\mathrm{B}_{1}$ recorded in each year was $1.0 \mu \mathrm{g} \mathrm{g}^{-1}$ in 1996, $2.1 \mu \mathrm{g} \mathrm{g}^{-1}$ in $1997,3.0 \mu \mathrm{g} \mathrm{g}^{-1}$ in 1998 , and $4.0 \mu \mathrm{g} \mathrm{g}^{-1}$ in 1999.

DON was more prevalent than fumonisin in grain corn samples; the proportion of samples that tested positive for DON $\left(>0.2 \mu \mathrm{g} \mathrm{g}^{-1}\right)$ varied from 47 to $95 \%$ depending on the hybrid type (transformed versus nontransformed) and year (Table 1). The non- $B t$ checks were removed from subsequent analyses comparing $B t$ hybrids and their non- $B t$ isolines because concentrations of DON did not differ between the non- $B t$ checks and non- $B t$ isolines when averaged across years $(P=0.34$; data not shown).

Concentrations of DON were different in $B t$ versus non- $B t$ hybrids; however, the magnitude of the response interacted with year, which resulted in a significant corn hybrid type by year interaction $(P=$ 0.0138; Table 2). Depending on the year between 1996 and 1998, the use of Bt hybrids reduced concentrations of DON from 30 to $64 \%(0.0001<P<0.02)$ compared with their non- $B t$ counterparts. Mean DON concentrations in 1999 were the same among $B t$ and non- $B t$ hybrids. Across all years, concentrations of DON were $40 \%$ lower $(P<0.0001)$ in $B t$ hybrids than in non- $B t$ isolines. Furthermore, we did not detect a difference in concentrations of DON among $B t$ hybrids containing event 176 compared with those containing $B t 11$ in any of the 4 years $(P>0.41$; data not shown).

Although $B t$ hybrids reduced concentrations of DON compared with non- $B t$ isolines, the magnitude of the reduction was dependent on the intensity of ECB activity as estimated by mean tunnel lengths. Data were combined across 1996 and 1997 because ECB injury among non- $B t$ hybrids was similar in both years (mean tunnel 
lengths of $4.9 \mathrm{~cm}$ per stalk in $1996 \mathrm{com}-$ pared with $4.3 \mathrm{~cm}$ in 1997), plus the response in DON to ECB injury did not interact with year $(P=0.22$; data not shown). In fields where ECB injury was "low" (as assessed by $<4 \mathrm{~cm}$ of tunneling per plant) in non- $B t$ hybrids, concentrations of DON in $B t$ versus non- $B t$ hybrids were similar $(P$ $=0.1088$; Table 3 ); mean concentrations of DON in $B t$ hybrids averaged $0.36 \mu \mathrm{g} \mathrm{g}^{-1}$ compared with $0.54 \mu \mathrm{g} \mathrm{g}^{-1}$ in non-Bt isolines. However, in fields where ECB injury was "high" (injury of $>4 \mathrm{~cm}$ of tunneling per plant), concentrations of DON were reduced by $59 \%$ in $B t$ hybrids $(P=0.0011$; Table 3$)$; $B t$ hybrids in those fields averaged $0.39 \mu \mathrm{g} \mathrm{g}^{-1}$ of DON compared with $0.95 \mu \mathrm{g} \mathrm{g}^{-1}$ in non-Bt isolines (Table 3 ).

A quadratic relationship was identified between a measurement of ECB intensity (i.e., assessed by ECB tunnel length in stalks) and the DON content at harvest:

$$
\begin{aligned}
\text { DON }= & \exp (-1.298+0.321 \text { ECBTUNNEL } \\
& \left.-0.016(\text { ECBTUNNEL })^{2}\right)-0.1
\end{aligned}
$$

where DON is the concentration of deoxynivalenol $\left(\mu \mathrm{g} \mathrm{g}^{-1}\right)$ and ECBTUNNEL is the average tunnel length $(\mathrm{cm})$ per stalk from ECB feeding. Even though only $18 \%$ of the variability in DON was explained by the model, the parameter estimates for the prediction were all highly significant with $P<0.0005$ (Table 4). The relationship of DON and ECB intensity was not different among non- $B t$ and $B t$ hybrids $(P>0.50$; data not shown). In other words, neither the proportion of variability explained by the relationship nor the parameter estimates changed when data from $B t$ hybrids were removed from the equation. Thus, data from all hybrids were combined for the development of one equation. In general, DON content increased as the injury from ECB feeding intensified.

It was difficult to associate mean air temperatures, rainfall amounts, and frequencies of rainfall to mean DON contents across the study area in every year. Concentrations of DON were the lowest in 1997, which was also the year with the lowest rainfall and coolest temperatures during the period from 9 July to 19 August (data not shown).

\section{DISCUSSION}

The fact that no relationship was found between intensities of ECB or the use of $B t$ hybrids and concentrations of fumonisin at harvest in our study does not contradict the findings of Munkvold et al. (15). Concentrations of fumonisin in the majority of samples were near or below the lower detection limit between 1996 and 1999 because there were no excessively hot and dry conditions during the grain fill period (data not shown). In fact, hot and dry conditions, which favor fumonisin $\mathrm{B}_{1}$ production in corn (14), are rare in the northern corn production areas of North America. Other researchers have found ECB damage in corn to increase Fusarium moniliforme and fumonisin concentrations in grain at harvest (10). However, our findings suggest that the advantage of $B t$ corn for fumonisin management may only extend to environments where the risk of ECB injury is high and the environment is conducive to fumonisin-producing Fusaria.

The use of $B t$ corn reduced mean concentrations of DON by more than $59 \%$ compared with those in non- $B t$ hybrids when the intensity of ECB was high ( $>4$ $\mathrm{cm}$ on tunnels in the stalks of non- $B t$ plants). Other studies have also found $B t$ corn to reduce DON (18). We assume that all non- $B t$ hybrids had a similar response because there was no evidence to suggest that concentrations of DON were better (i.e., lower) in popular non- $B t$ check hybrids compared with the non- $B t$ isolines used in this study. Furthermore, even though we did not directly measure ECB injury to corn ears, we assumed that damage caused by stalk tunneling was a good measure ECB activity. In other words, those fields with greater lengths of stalk tunneling were assumed to have greater ear damage than other fields with lower stalk tunneling. Higher concentrations of DON in hybrids susceptible to ECB injury (i.e., non- $B t$ hybrids) suggests that the main entry of Fusarium graminearum into corn ears occurred through sites of ECB injury (19). This injury was assumed to be minimal in $B t$ hybrids because the $B t$ Cry IA (b) toxin is specific to ECB and a few other lepidopterous insects (11). This is supported by the quadratic relationship be- tween concentration of DON and ECB stalk injury, assuming that stalk tunneling is correlated with the level of injury on the ears of corn. It is important to note, however, that $F$. graminearum can also enter the ears of corn through silk channels and wounds caused by other insects and hail damage; drought stress has also been shown to increase wounds in corn ears (19). Therefore, we recommend with caution the use of $B t$ corn to reduce the potential concentrations of DON contamination because protection against ECB injury to corn ears will have no impact on the development of silk channel infections for $F$. graminearum or other Fusarium species.

No differences in concentrations of DON could be detected between event $B t 11$ and 176 among $B t$ hybrids. We expected that the concentration of DON may be lower in hybrids transformed with $B t 11$ because the Cry IA (b) protein is expressed in all tissue including tissue in the ear; event 176 only expresses the protein in green leaf tissue and not in the ear or kernel (23). On the other hand, other researchers have observed reduced mycotoxins with 176 compared with non-Bt hybrids because larvae feeding on the leaves or husks may not survive long enough to injure ears sufficiently for infection by Fusaria (G. P. Munkvold, Iowa State University, personal communication). Indeed, it is possible that differences between the events may become more evident under severe epidemics.

To avoid ill-founded expectations, however, recommendations for using $B t$ corn to

Table 3. Mean deoxynivalenol (DON) concentrations in grain samples of corn as affected by intensities of European corn borer (ECB) in $B t$ and non- $B t$ corn hybrids from farm field strip trials from

\begin{tabular}{|c|c|c|c|c|}
\hline \multirow[b]{3}{*}{ Corn type/contrasts } & \multicolumn{4}{|c|}{ Intensities of ECB ${ }^{\mathbf{a}}$} \\
\hline & \multicolumn{2}{|c|}{ Low } & \multicolumn{2}{|c|}{ High } \\
\hline & $\begin{array}{l}\text { DON } \\
\mu g g^{-1}\end{array}$ & $\begin{array}{c}\text { No. paired } \\
\text { observations }\end{array}$ & $\begin{array}{l}\text { DON }^{b} \\
\mu g^{-1}\end{array}$ & $\begin{array}{c}\text { No. paired } \\
\text { observations }\end{array}$ \\
\hline \multicolumn{5}{|l|}{ Corn type } \\
\hline Non- $B t$ isoline & 0.54 & 16 & 0.95 & 19 \\
\hline Bt & 0.36 & & 0.39 & \\
\hline Mean within intensity of ECB & 0.44 & & 0.60 & \\
\hline Contrasts & & & & $P$ \\
\hline \multicolumn{3}{|l|}{ Isoline vs. $B t$} & & 0.0009 \\
\hline \multicolumn{3}{|c|}{ ECB Injury: low vs. high } & & 0.2263 \\
\hline \multicolumn{3}{|c|}{ Low intensities of ECB injury: isoline vs. $B t$} & & 0.1088 \\
\hline \multicolumn{3}{|c|}{ High intensities of ECB injury: isoline vs. $B t$} & & 0.0011 \\
\hline
\end{tabular}
1996 to 1999

${ }^{\text {a }}$ Fields were classed with low ECB intensities when tunnels of $<4-\mathrm{cm}$ per stalk were observed in each non- $B t$ corn isoline.

${ }^{\mathrm{b}} \mathrm{DON}$ concentrations are presented as detransformed means from $\ln (\mathrm{DON}+0.1)$.

Table 4. Regression statistics for predicting deoxynivalenol (DON) in grain corn from observations of European corn borer (ECB) tunnel lengths from farm strip trials in 1996 and 1997a

\begin{tabular}{lccc}
\hline Parameter $^{\mathbf{b}}$ & Parameter estimate $^{\mathbf{c}}$ & $\mathbf{S E}$ & $\boldsymbol{P}>\boldsymbol{F}$ \\
\hline Intercept & -1.298 & 0.1688 & $<0.0001$ \\
ECBTUNNEL & 0.321 & 0.0706 & $<0.0001$ \\
ECBTUNNEL $^{2}$ & -0.016 & 0.0044 & 0.0005 \\
\hline
\end{tabular}

${ }^{a}$ Adjusted model $R^{2}=0.18(P<0.0001)$; mean square error $(\mathrm{MSE})=1.349$ with $112 \mathrm{df}$.

${ }^{\mathrm{b}}$ ECBTUNNEL $=$ average length $(\mathrm{cm})$ of ECB burrow in corn stalks from all $B t$ and non- $B t$ hybrids.

${ }^{c}$ DON concentrations were transformed using $\ln (\mathrm{DON}+0.1)$ before analysis. 
reduce concentrations of DON at harvest must be accompanied with caution that this approach may have serious, inherent limitations. For example, rainfall and temperature at silking and during the period of ear fill for corn have been considered more important than insect injury in ear rot epidemics caused by Fusarium spp. in Ontario $(14,19,24)$; different conditions cause shifts in the Fusarium spp. involved. Furthermore, DON was correlated to ECB injury, suggesting that the intensity of ECB can also be important for ear rot epidemics in the northern part of the corn production belt of North America. In Iowa, ECB injury is a dominant factor in Fusarium ear rot and the development of fumonisin (15). Therefore, this study supports the use of $B t$ corn to reduce the risk of potentially high concentrations of DON at harvest. This is particularly important if concentrations of mycotoxins cause concern for swine production (13).

\section{ACKNOWLEDGMENTS}

We thank the Ontario Corn Producers' Association, Pioneer Hi-bred Canada Ltd., and the Canadian Adaptation Council for financial support. Assistance with site selection and sample collection by Syngenta Seeds Canada Ltd. is gratefully acknowledged. Harvesting was conducted by many different corn producers. Laboratory and field technical support by Diane Paul and Todd Phibbs of Ridgetown College, University of Guelph, is greatly appreciated.

\section{LITERATURE CITED}

1. Attwater, W. A., and Busch, L. V. 1983. Role of sap beetle Glischrochilus quadrisignatus (Coleoptera: Nitidulidae) in the epidemiology of gibberella corn ear rot. Can J. Plant Pathol.5:158-163.

2. Baute, T. S., Sears, M. K., and Schaafsma, A. W. 2002. Using transgenic Bacillus thuringiensis Berliner corn hybrids to determine the direct economic impact of the European corn borer, Ostrinia nubilalis (Hübner) (Lepidoptera: Crambidae) on field corn in eastern Canada. J. Econ. Entomol. 95:57-64.

3. Betz, S. B., Hammond, B. G., and Fuchs, R. L. 2000. Safety and advantages of Bacillus thuringiensis-protected plants to control in- sect pests. Reg. Toxicol. Pharmacol. 32:156173.

4. Bowerman, B. L., and O'Connell, R. T. 1990. Dummy variables and advanced statistical inferences. Pages 555-599 in: Linear Statistical Models: An Applied Approach. 2nd ed. Duxbury Thomson Learning, Pacific Grove, CA.

5. Brown, D. M., and Bootsma, A. 1993. Crop heat units for corn and other warm-season crops in Ontario. Ontario Ministry of Agriculture and Food Factsheet Agdex 111/31. ISSN No. 0225-7882. Ontario Ministry of Agriculture and Food, Queen's Park, Toronto, ON, Canada.

6. Christensen, J. J., and Schneider, C. L. 1950. European corn borer (Pyrausta nubilalis Hübn.) in relation to shank, stalk and ear rots of corn. Phytopathology 40:284-291.

7. Dowd, P. F. 1998. Involvement of arthropods in the establishment of mycotoxigenic fungi under field conditions. Pages 307-350 in: Mycotoxins in Agriculture and Food Safety. K. K. Sinha and D. Bhatnagar, eds. Marcel Dekker, New York

8. Dowd, P. F. 2000. Indirect reduction of ear molds and associated mycotoxins in Bacillus thuringiensis corn under controlled and open field conditions: Utility and limitations. J. Econ. Entomol. 93:1669-1679.

9. Dowd, P. F., Bennett, G. A., McGuire, M. R., Nelsen, T. C., Shasha, B. S., and Simmons, F. W. 1999. Adherent malathion flour granules as an environmentally selective control for chewing insect pests of dent corn ears: Indirect reduction of mycotoxigenic ear molds. J. Econ. Entomol. 92:68-75.

10. Lew, H., Adler, A., and Edinger, W. 1991. Moniliformin and the European corn borer. Mycotoxin Res. 7:71-76.

11. Martin, P. A. W. 1994. An iconoclastic view of Bacillus thuringiensis ecology. Am. Entomol. 40:85-90.

12. McMillian, W. W., Widstrom, N. W., Barry, D., and Lillehoj, E. B. 1988. Aflatoxin contamination in selected corn germplasm classified for resistance to European corn borer (Lepidoptera: Noctuidae). J. Entomol. Sci. 23:240-244.

13. Miller, J. D. 1994. Epidemiology of Fusarium ear diseases of cereals. Pages 19-35 in: Mycotoxins in Grains: Compounds Other than Aflatoxins. J. D. Miller and H. L. Trenholm, eds. American Phytopathological Society, St. Paul, MN.

14. Miller, J. D., Savard, M. E., Schaafsma, A. W., Seifert, K. A., and Reid, L. M. 1995. My- cotoxin production by Fusarium moniliforme and Fusarium proliferatum from Ontario and occurrence of fumonisin in the 1993 corn crop. Can. J. Plant Pathol. 17:233-239.

15. Munkvold, G. P., Hellmich, R. L., and Rice, L. G. 1999. Comparison of fumonisin concentrations in kernels of transgenic Bt corn hybrids and nontransgenic hybrids. Plant Dis. 83:130-138.

16. Munkvold, G. P., Hellmich, R. L., and Showers, W. B. 1997. Reduced fusarium ear rot and symptomless infection in kernels of maize genetically engineered for European corn borer resistance. Phytopathology 87:10711077.

17. Munkvold, G. P., McGee, D. C., and Carlton, W. M. 1997. Importance of different pathways for maize kernel infection by Fusarium moniliforme. Phytopathology 87:209-217.

18. Pietri, A., and Piva, G. 2000. Occurrence and control of mycotoxins in maize grown in Italy. Pages 226-236 in: Food Safety: Current situation and perspectives in the European Community. G. Piva and F. Masoero, eds. Proc. 6th Int. Feed Conf.

19. Schaafsma, A. W., Miller, J. D., Savard, M E., and Ewing, R. J. 1993. Ear rot development and mycotoxin production in corn in relation to inoculation method, corn hybrid, and species of Fusarium. Can. J. Plant Pathol. 15:185-192.

20. Schaafsma, A. W., Nicol, R. W., Savard, M. E., Sinha, R. C., Reid, L. M., and Rottinghaus, G. 1998. Analysis of Fusarium toxins in corn and wheat using thin layer chromatography. Mycopathologica 142:107-113.

21. Scott, P. M. 1984. Effects of food processing on mycotoxins. J. Food Prot. 47:489-499.

22. Sutton, J. C. 1982. Epidemiology of wheat head blight and corn ear rot caused by Fusarium graminearum. Can. J. Plant Pathol. 4:195-209.

23. Tenuta, A., Sears, M. K., Meloche, F., and Schaafsma, A. W. 1999. Controlling European Corn Borer with Bt Corn Technology: A Grower's Guide. Ontario Corn Producers Association. On-line publication.

24. Vigier, B., Reid, L. M., Seifert, K. A., Stewart, D. W., and Hamilton, R. 1997. Distribution and prediction of Fusarium species associated with corn ear rot in Ontario. Can. J. Plant Pathol. 19:60-65.

25. Widstrom, N. W., Sparks, A. N., Lillehoj, E. B., and Kwolek, W. F. 1975. Aflatoxin production and lepidopteran insect injury on corn in Georgia. J. Econ. Entomol. 68:855-856. 